\title{
Complete Larval Development of Saron marmoratus (Olivier, 1811) Reared Under Laboratory Conditions (Crustacea: Decapoda: Hippolytidae)
}

\author{
Farhana S. Ghory, Quddusi B. Kazmi, Feroz A. Siddiqui \\ Marine Reference Collection and Resource Centre, University of Karachi, Karachi-75270, Pakistan.

\begin{abstract}
The present paper is based on the results of laboratory rearing experiment of Saron marmoratus from the $1^{\text {st }}$ zoeal to $7^{\text {th }}$ postlarval stage. The ovigerous female of Saron marmoratus was collected from Buleji, Karachi on $09^{\text {th }}$ March, 1996 and maintained in the wet laboratory of Marine Reference Collection and Resource Centre, University of Karachi. Larvae were hatched on 17 th March, 1996, at room temperature of $26^{\circ} \mathrm{C}$ and water temperature $23^{\circ} \mathrm{C}$ in filtered seawater of a salinity of 35-37 ppt and pH 7.9 - 8.1. All the larval stages of Saron marmoratus are described along with their illustrations, and compared with the available descriptions of Saron marmoratus larvae earlier studied.
\end{abstract}

Keywords: Decapoda, Hippolytidae, Larval development, Saron marmoratus, Pakistan.

\section{INTRODUCTION}

Saron marmoratus (Olivier, 1811) is the only representative of the genus Saron of family Hippolytidae as reported by Kemp (1914) from Pakistan. It was found from various localities of Pakistan coast of the Northern Arabian Sea (Kazmi and Kazmi, 1979; 2012).

The species being widely distributed but the larvae are only described four times. First documented based on two early stages by Gurney (1937), one laboratory reared and other one was planktonic. Then in 1961 Al-Kholy described Red Sea material up to first four larval stages obtained through laboratory rearing. Later on Sankolli and Kewalramani (1962) obtained eight larval stages, from protozoea to fourth post-larva from India. Lastly Maihara and Kyoya (2002) were able to obtain six stages, four zoeal, one decapodid, and one juvenile stage. Present deliberations is based on laboratory reared larvae from ovigerous female of this species collected from Buleji Karachi (Pakistan) in thirteen stages, six zoeal stages and seven post-larval stages. We have noted morphological as well as developmental differences, both environmental and laboratory conditions differed between the present and previous studies, which may have accounted for the variations observed and which are given in tabulated form. The zoeal and post -larval stages are described along with their illustrations.

\section{Materials AND Methods}

An ovigerous female of Saron marmoratus (Olivier, 1811) (Plate 1) measuring $69 \mathrm{~mm}$ was obtained from Buleji (long 66 $49^{\prime} 12^{\prime \prime} \mathrm{E}$, lat $24^{\circ} 50^{\prime} 12^{\prime \prime} \mathrm{N}$ ) on $09^{\text {th }}$ March, 1996. The ovigerous female was kept in the laboratory in filtered seawater with a salinity of 35-37\%o and $\mathrm{pH} 7.9-8.1$ at room temperature $\left(23^{\circ} \mathrm{C}-26^{\circ} \mathrm{C}\right)$. The larvae were hatched on $17^{\text {th }}$ March, 1996. Newly hatched larvae were segregated and placed, five larvae per beaker $(500 \mathrm{ml})$, containing filtered seawater. Artemia nauplii were offered as food. Each beaker was examined daily for exuviae and dead larvae. Temporary slides were made by using glycerin plus 5\% formalin (3:1). The specimens were dissected by using tungsten needle under a binocular microscope (Nikon) with 10x/21 magnifications. The illustrations were made with the help of Olympus BX51 microscope (magnifications WHN10X/22 x10, 20 and 40) with Nomarski interference contrast and camera lucida attachment. Measurements (millimeter $=\mathrm{mm}$ ) of illustrated specimens were made by using stage micrometer. The total length (TL) was determined from the tip of the rostrum to the mid posterior border of the telson.

The spent female and the remaining larvae were deposited in the Marine Reference Collection and Resource Centre, University of Karachi. (Cat. No. CARI. 255). 


\section{Results}

\section{Description of the larvae}

(Figs. 1-27)

Zoea I (Figs. 1A - 2H)

Size:- TL $=3.76 \mathrm{~mm}-3.94 \mathrm{~mm}$

Duration:- 4 days

Diagnostic Features: Carapace (Figs. 1A, B) Carapace smooth with a mediodorsal hump; rostrum small; eyes stalked. Antennule (Fig. 1C) peduncle 3-segmented, distal segment with 1 long plumose seta; outer ramus with 2 aesthetascs and 1 spatulate shape seta. Antenna (Fig. 1D) biramous; peduncle with a distal spine on inner margin; endopod small, broad, ending in a point with few setae; scaphocerite (exopod) 4-segmented with 11 plumose setae. Mandible (Fig. 1E) well developed. Maxillule (Fig. 1F) coxal endite with 7 plumodenticulate setae; basial endite with 13 cuspidate setae; endopod with 5 plumodenticulate setae. Maxilla (Fig. 1G) coxal and basial endites bilobed with 16+4 and 8+9 plumodenticulate setae; endopod with 9 plumodenticulate setae; scaphognathite with 5 setae. Maxilliped I (Fig. 2A) coxopod with 4 plumodenticulate setae; basipod with 15 plumodenticulate setae; endopod 4-segmented with 4,2,1 and 3 plumodenticulate setae; exopod 4-segmented with 0, 2, 2, and 2 plumose natatory setae, respectively. Maxilliped II (Fig. 2B) coxopod with 3 and basipod with 2 plumodenticulate setae; endopod 5-segmented with 2, 3, 1, 2+1 and 5 plumodenticulate setae, respectively; exopod 2 terminal and 4 subterminal plumose natatory setae. Maxilliped III (Fig. 2C) basipod with 3 plumodenticulate setae; endopod 5-segmented with 2, 0, 0, 2 and 2 plumodenticulate setae, respectively; exopod 4-segmented with 0, 2, 0, 4 plumose natatory setae, respectively. Pereiopods I-V (Figs. 2D-H) biramous, rudimentary. Pleopod (Fig. 1H) rudimentry. Abdomen (Fig. 1A, H) five somites with rounded posteriolateral angles. Telson (Fig. 1A, I) triangular; posterior margin with 6 pairs and posteriolateral margin with 1 pair of plumose setae.

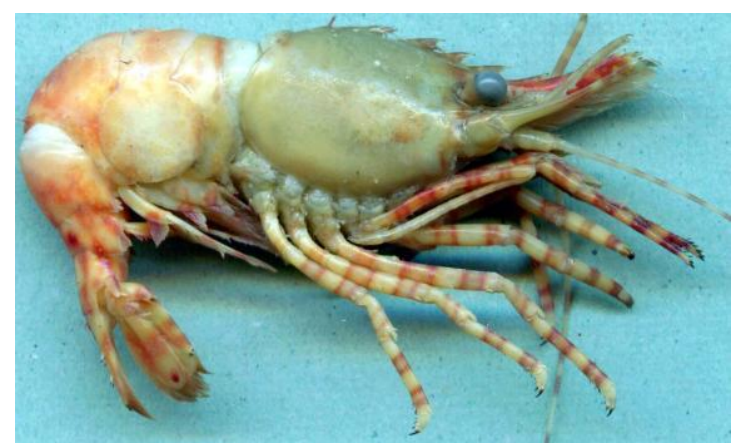

Plate1. Ovigerous female of Saron marmoratus (Olivier, 1811)

Fig1. Saron marmoratus (Olivier, 1811). Zoea I: A, entire, dorsal view; B, lateral view of carapace; C, antennule; D, antenna; $E$, mandible; $F$, maxillule; $G$, maxilla, $H$, abdomen with telson, lateral view; $I$, telson, dorsal view

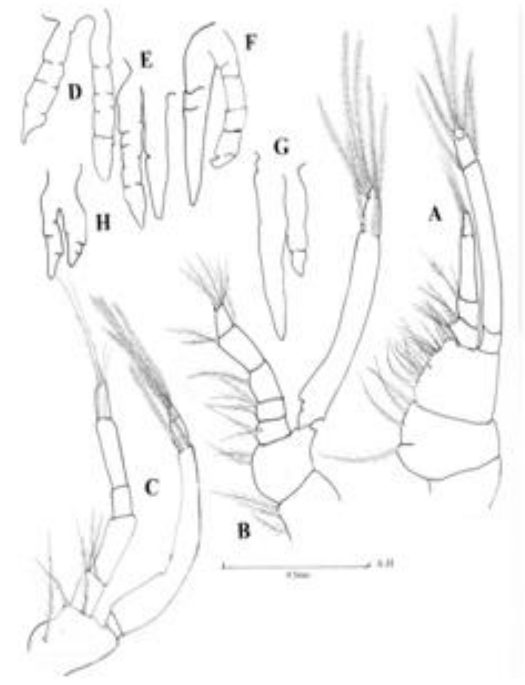

Fig2. Saron marmoratus (Olivier, 1811). Zoea I: A-C, maxillipeds I-III; D-H, pereiopods I-V 
Zoea II (Figs. 3A - 4I)

Size:- TL $=3.00 \mathrm{~mm}-3.26 \mathrm{~mm}$

Duration:- 4 days

Diagnostic Features: Carapace (Figs. 3A, B) smooth with a mediodorsal hump; rostrum small; eyes stalked. Antennule (Fig. 3C) peduncle 2-segmented with 5 and 4 plumodenticulate setae, respectively; inner ramus (endopod) with 1 plumodenticulate seta; outer ramus (exopod) with 4 aesthetscs and 1 spatulate shape seta. Antenna (Fig. 3D) unchanged, except number of scaphocerite (exopod) setae increased. Mandible (Fig. 3E) well developed. Maxillule (Fig. 3F) coxal endite with 10 plumodenticulate setae; basial endite with 13 cuspidate and 1 plumodenticulate seta; endopod with 5 plumodenticulate setae. Maxilla (Fig. 4A) coxal and basial endites bilobed with $16+4$ and $8+9$ plumodenticulate setae, respectively; endopod with 6 plumodenticulate setae; scaphognathite with 15 setae. Maxilliped I (Fig. 4B) coxopod with 8 plumodenticulate setae; basipod with 18 plumodenticulate setae; endopod 4-segmented with 4, 1, 2+1 and 3 plumodenticulate setae, respectively; exopod segmented with 1 seta of proximal segment and 4 terminal setae ( 2 setae broken). Maxilliped II (Fig. 4C) coxopod with 1 seta; basipod with 7 plumodenticulate setae; endopod 5 -segmented with $3+1,1,1,2+1$ and $7+1$ plumodenticulate setae, respectively; exopod with 2 terminal and 4 subterminal plumose natatory setae. Maxilliped III (Fig. 4D) coxopod broken; basipod with 3 plumodenticulate setae; endopod 5-segmented with 1,1,1,2 and 4 plumodenticulate setae, respectively; exopod with 4 terminal and 2 subterminal plumose natatory setae. Pereiopods I-V (Figs. 4E-I) biramous, rudimentary. Pleopods (Fig. 3G) rudimentary. Abdomen (Figs. 3A, G) five somites with rounded posteriolateral angles. Telson (Fig. 3A, G) posterior margin with 7 pairs and posteriolateral margin with 1 pair of plumose setae.

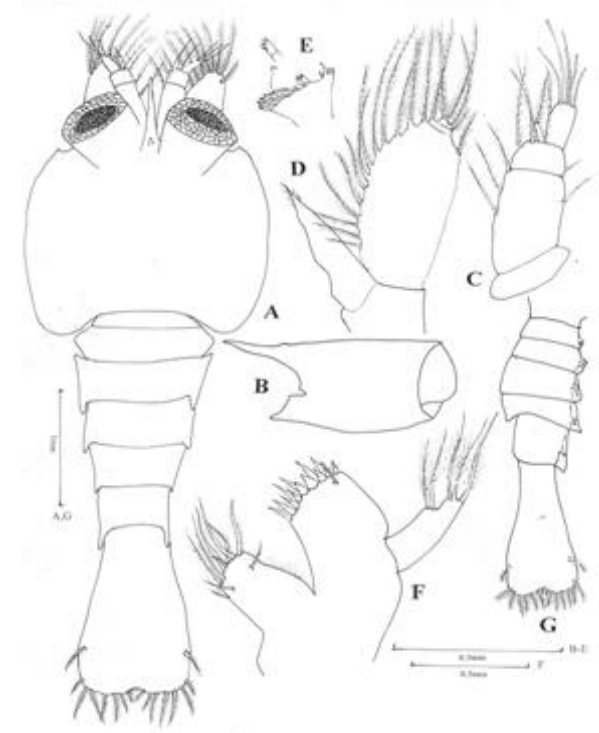

Fig3. Saron marmoratus (Olivier, 1811). Zoea II: A, entire, dorsal view; B, lateral view of carapace; C, antennule; $D$, antenna; $E$, mandible; $F$, maxillule; $G$, abdomen with telson.

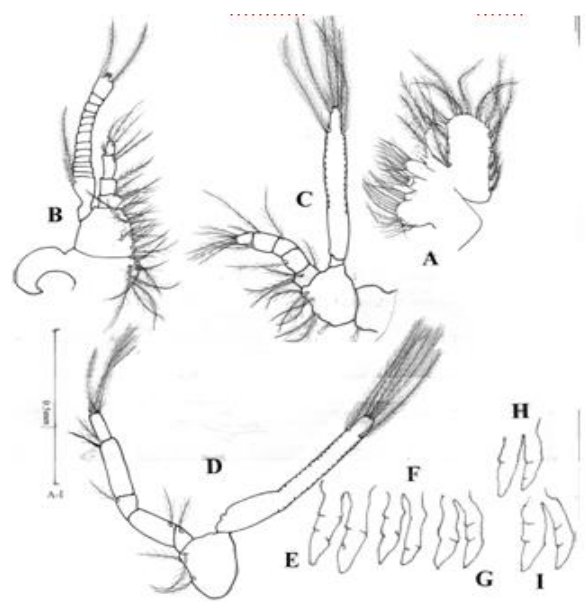

Fig4. Saron marmoratus (Olivier, 1811). Zoea II: A, maxilla; B - D, maxillipeds I-III; E - I, pereiopods I - V 
Zoea III (Figs. 5A - 6I)

Size:- $\mathrm{TL}=3.30 \mathrm{~mm}-3.55 \mathrm{~mm}$

Duration:- 2 days

Diagnostic Features: Carapace (Figs. 5A, B) carapace smooth with a mediodorsal hump; rostrum small; eyes stalked. Antennule (Fig. 5C) peduncle 2-segmented with 12 and 5 plumodenticulate setae, respectively; inner ramus (endopod) unchanged; outer ramus (exopod) with 3 aesthetascs and 3 setae. Antenna (Fig. 5D) biramous, endopod 2-segmented and naked; number of scaphocerite (exopod) setae increased. Mandible (Fig. 5E) well developed. Maxillule (Fig. 5F) coxal endite with 10 setae; basial endite with 12 cuspidate and 3 setae; endopod with 5 plumodenticulate setae. Maxilla (Fig. 6A) coxal and basial endites bilobed with $11+4$ and 10+7 plumodenticulate setae, respectively; endopod with 8 plumodenticulate setae; scaphognathite with 19 setae. Maxilliped I (Fig. 6B) coxal endite with 11 and basial endite with 18 plumodenticulate setae; endopod 4-segmented with 4, 1, 2 and 3 plumodenticulate setae, respectively; exopod with 2 terminal and 5 subterminal plumose natatory setae. Maxilliped II (Fig. 6C) coxopod naked; basipod with 4 plumodenticulate setae; endopod 5segmented with 2, 2, 1, 4 and 3 plumodenticulate setae, respectively; exopod with 2 terminal and 4 subterminal plumose natatory setae. Maxilliped III (Fig. 6D) coxopod naked; basipod with 3 plumodenticulate setae; endopod 5-segmented with $2,2,2,5$ and 3 plumodenticulate setae, respectively; exopod 2-segmented with 2 terminal and 6 subterminal long plumose natatory setae. Pereiopods I-V (Figs. 6E-I) biramous, pereiopod I (Fig. 6E), coxopod naked; basipod with 3 setae; 5segmented, endopod with 2, 2, 2.4 and 3 setae, respectively; 2-segmented, exopod distal segment with 2 terminal and 6 subterminal plumose natatory setae; pereiopod II (Fig. 6F) coxa naked; basis with 4 plumodenticulate setae; 5-segmented, endopod with 1, 1, 0,3 and 3+1 plumodenticulate setae, respectively; exopod with 4 terminal and 6 subterminal plumose natatory setae; pereiopod III (Fig. 6G) coxa naked; basis with 2 plumodenticulate setae; 5-segmented, endopod with 0, 0, 0, 2 and 3 plumodenticulate setae, respectively; exopod with 2 terminal and 6 subterminal plumose natatory setae; pereiopod IV and V (Figs. 6H, I) biramous, rudimentary. Pleopod (Fig. 5G) biramous, rudimentary. Abdomen (Figs. 5A, G) five somites with rounded posteriolateral angles. Telson (Fig. $5 \mathrm{H})$ posterior margin with 7 pairs of plumose setae; uropod developed, endopod with 2 simple setae; exopod with 13-14 long plumose natatory setae.

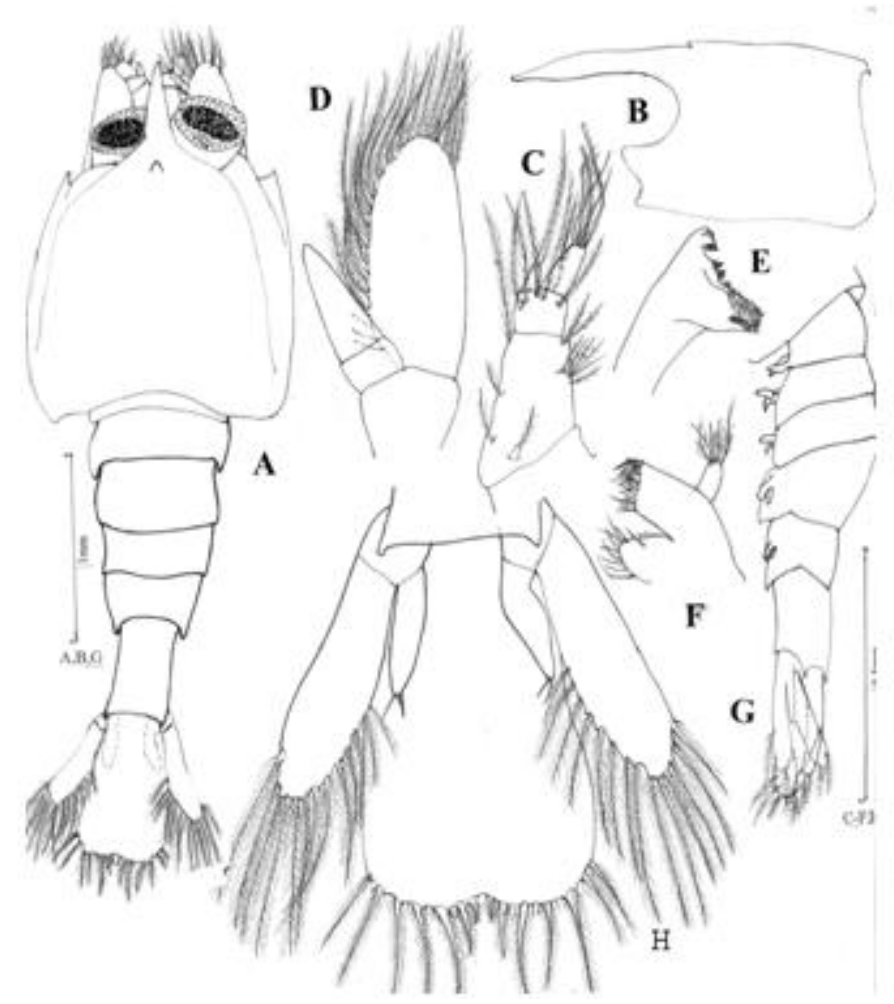

Fig5. Saron marmoratus (Olivier, 1811). Zoea III: A, entire, dorsal view; B, lateral view of carapace; C, antennule; $D$, antenna; $E$, mandible; $F$, maxillule; $G$, abdomen with telson, lateral view; $H$, telson with uropods 


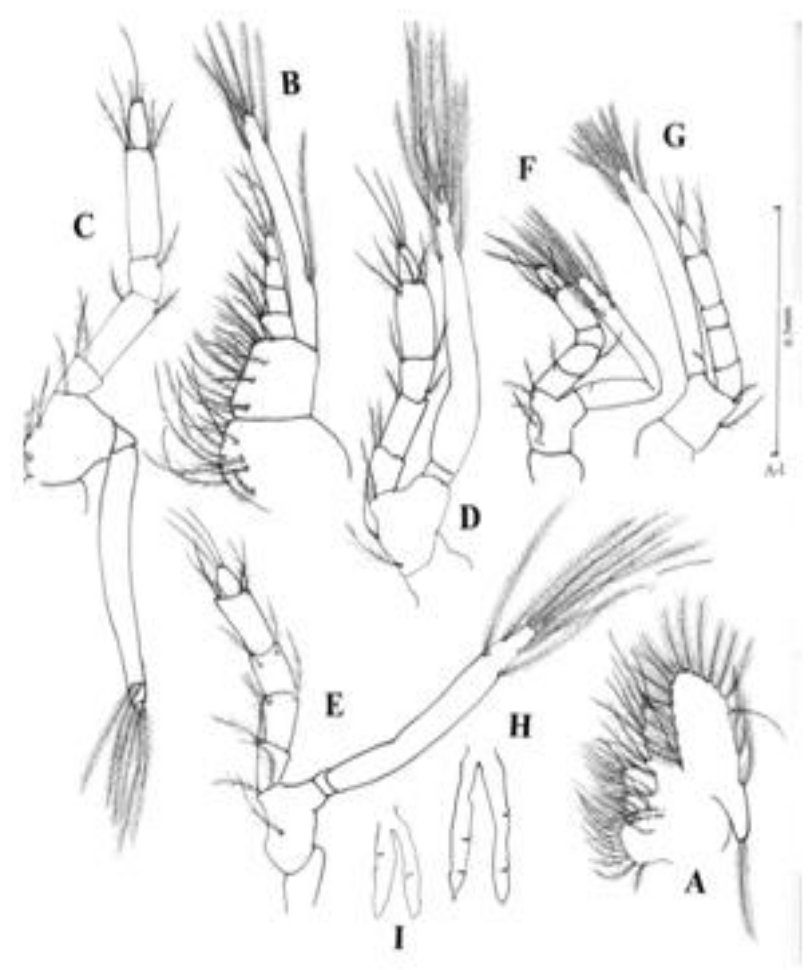

Fig6. Saron marmoratus (Olivier, 1811). Zoea III: A, maxilla; B - D, maxillipeds I-III; E - I, pereiopods I -V

Zoea IV (Figs. 7A - 10D)

Size:- $\mathrm{TL}=4.23 \mathrm{~mm}-4.46 \mathrm{~mm}$

Duration:- 5 days

Diagnostic Features: Carapace (Figs. 7A, B) carapace smooth with a mediodorsal hump and one small posterior marginal spine present; rostrum with 3 spines on ventral side. Antennule (Fig. 8A) peduncle 2-segmented, proximal segment with 2 spines and 14 plumodenticulate setae, distal segment with 10 plumodenticulate setae; inner ramus (endopod) with 1 plumodenticulate setae; outer ramus (exopod) with 6 aesthetascs. Antenna (Fig. 8B) biramous; endopod 2-segmented, distal segment with 2 simple setae; number of scaphocerite (exopod) setae increased. Mandible (Fig. 8C) well developed. Maxillule (Fig. 8D) coxal endite with 13 plumodenticulate setae; basial endite with 14 cuspidate and 2 plumodenticulate setae; endopod with 2 terminal and 2 subterminal plumose setae.

Maxilla (Fig. 8E) coxal and basial endites bilobed with $12+5$ and $4+7$ plumodenticulate setae, respectively; endopod with 9 plumodenticulate setae; scaphognathite with 34 setae. Maxilliped I (Fig. 8F) coxal endite with 8 and basial endite with 14 plumodenticulate setae; endopod 4-segmented with 4, 1,1 and 2 plumodenticulate setae, respectively; exopod with 2 terminal and 3 subterminal long plumose setae. Maxilliped II (Fig. 8G) coxal endite broken; basial endite with 1 seta; endopod 5segmented with $0,1,2,4$ and 3+1 plumodenticulate setae, respectively; exopod 2-segmented, distal segment with 2 terminal and 6 subterminal plumose setae. Maxilliped III (Fig. 9A) basipod naked; endopod 5-segmented with 1, 2, 3, 4 and 3 plumodenticulate setae, respectively; exopod 2-segmented, distal segment with 2 terminal and 6 subterminal long plumose natatory setae. Pereiopods I-V (Figs. 9B, C \& 10A-C) pereiopods I-V biramous; pereiopod I (Fig. 9B) basial endite with 2 setae; endopod 5-segmented with 3, 2, 2, 2 and 3 plumodenticulate setae, respectively; exopod unchanged; pereiopod II (Fig. 9C) basial endite naked; endopod 4-segmented with 2,3,3 and 4+2 plumodenticulate setae, respectively, distal segment chelate; exopod with 4 terminal and 6 subterminal plumose natatory setae; pereiopod III (Fig. 10A) basial endite with 4 plumodenticulate setae; endopod 4-segmented with 2, 2, 2 and 5+2 plumodenticulate setae, respectively, distal segment chelate; exopod with 2 terminal and 6 subterminal plumose natatory setae; pereiopods IV and V (Figs. 10B \& C) rudimentary. Pleopod (Fig. 10D) biramous; exopod with 1 simple seta. Abdomen (Fig. 7A, C) five somites with rounded posteriolateral angles. Telson (Fig. 7D) posterior margin with 5 pairs of plumose setae; uropod (Fig. 7D) exopod and endopod with several long plumose setae. 


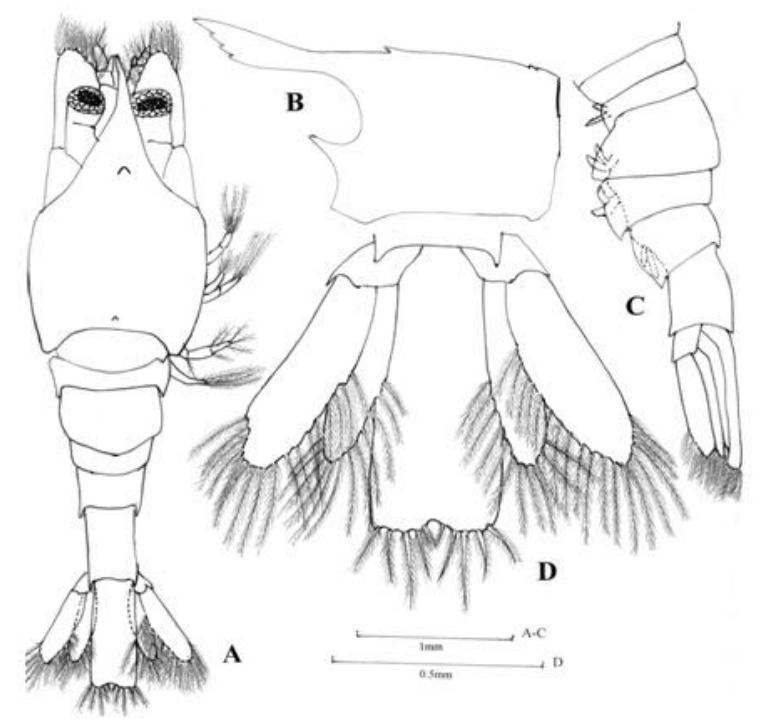

Fig7. Saron marmoratus (Olivier, 1811). Zoea IV: A, entire, dorsal view; B, lateral view of carapace; C, abdomen with telson, lateral view; $D$, telson, with uropods

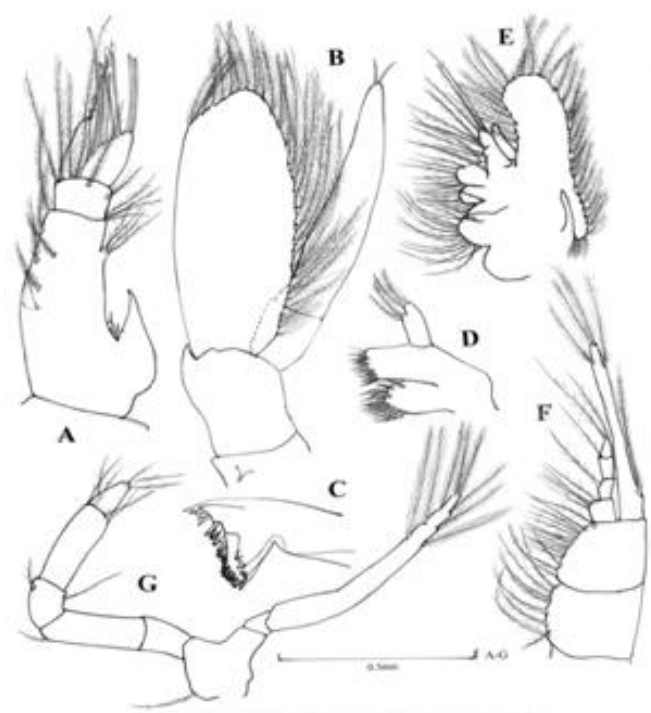

Fig8. Saron marmoratus (Olivier, 1811). Zoea IV: A, antennule; $B$, antenna; $C$, mandible; $D$, maxillule; $E$, maxilla; $F, G$, maxillipeds I, II

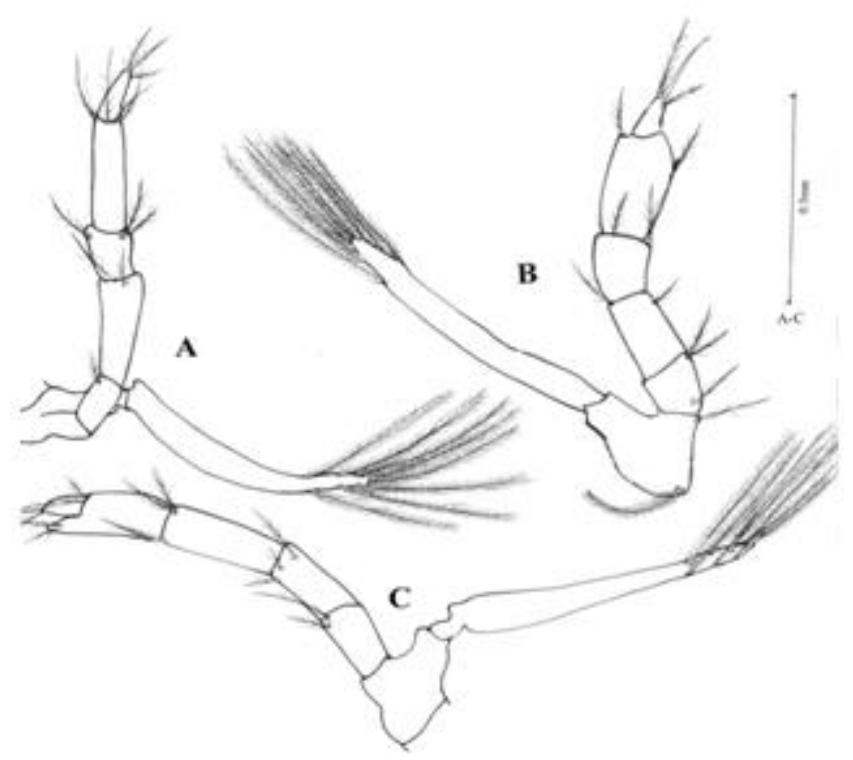

Fig9. Saron marmoratus (Olivier, 1811). Zoea IV: A, maxilliped III; B, C, pereiopods I, II 


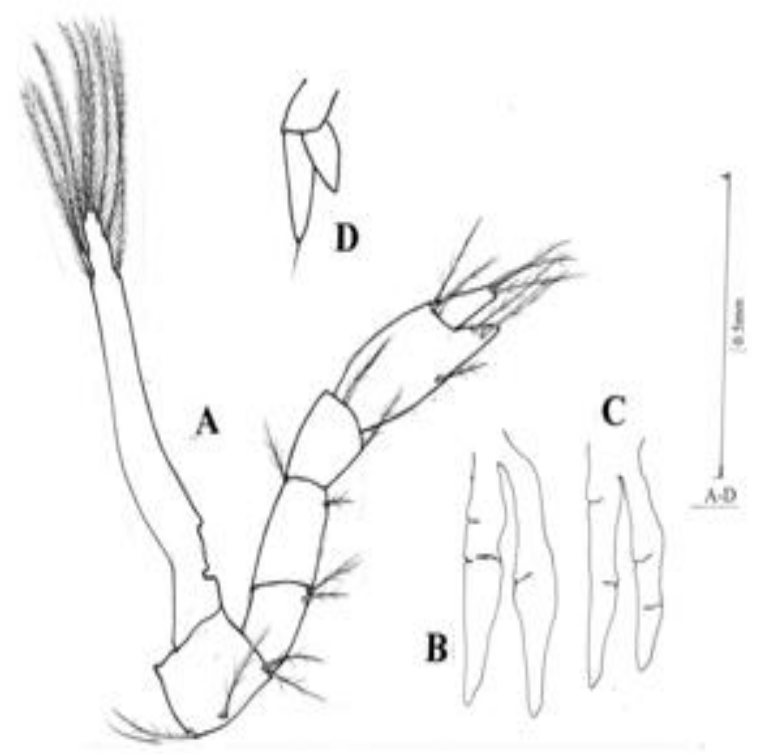

Fig10. Saron marmoratus (Olivier, 1811). Zoea IV: A-C, pereiopods III-V; D, pleopod

Zoea V (Figs. 11A - 13E)

Size:- $\mathrm{TL}=5.73 \mathrm{~mm}-6.49 \mathrm{~mm}$

Duration:- 6 days

Diagnostic Features: Carapace (Fig. 11A) smooth with a mediodorsal hump and one small posterior marginal spine present; rostrum with 1 spine on the dorsal side and 3 on the ventral side; pterygostomian spine present. Antennule (Fig. 12B) peduncle 3-segmented with 2 spines +10 setae; 5 and 7 plumodenticulate setae, respectively; inner ramus (endopod) with 2 plumodenticulate setae; outer ramus (exopod) with 9 aesthetascs. Antenna (Fig. 11A) biramous, endopod 2-segmented, distal segment with 11 simple setae; number of scaphocerite (exopod) setae increased. Mandible (Fig. 12B) well developed. Maxillule (Fig. 12C) coxal endite with 10 plumodenticulate setae; basial endite with 13 cuspidate spines; endopod with 3 terminal and 2 subterminal plumodenticulate setae. Maxilla (Fig. 12D) coxal and basial endites bilobed with $10+3$ and $8+8$ plumodenticulate setae; endopod with 10 plumodenticulate setae; scaphognathite with 34 setae. Maxilliped I (Fig. 12E) coxal endite with 10 plumodenticulate setae; basial endite with 19 plumodenticulate setae; endopod 4-segmented with 5, 1, 2, 2+1 plumodenticulate setae, respectively; exopod with 2 terminal and 5 subterminal plumose natatory setae. Maxilliped II (Fig. 12F) coxal endite with 2 plumodenticulate setae; basial endite with 10 plumodenticulate setae; endopod 5-segmented with $3,1,1,2+2$ and 7 plumodenticulate setae, respectively; exopod with 2 terminal and 4 subterminal plumose natatory setae.

Maxilliped III (Fig. 12G) coxal endite with 1 seta; basial endite with 3 plumodenticulate setae; endopod 5-segmented with 2, 2, 2, 6 and 4+1 plumodenticulate setae, respectively; exopod 2segmented, distal segment with 2 terminal and 6 subterminal plumose natatory setae. Pereiopods I-V (Figs. 13A-E) biramous, pereiopod I (Fig. 13A) basipod with 2 plumodenticulate setae; endopod 5segmented with 3,2,1, 3 and 2+1 plumodenticulate setae, respectively; exopod 2-segmented, distal segment with 2 terminal and 6 subterminal plumose natatory setae; pereiopod II (Fig. 13B) coxal endite naked; basial endite with 3 plumodenticulate setae; endopod 4-segmented with 2, 2, 2 and 4+4 plumodenticulate setae, respectively; exopod 2-segmented, distal segment with 2 terminal and 6 subterminal long plumose natatory setae; pereiopod III (Fig. 13C) coxopod with 1 seta; basipod with 3 plumodenticulate setae; endopod 4-segmented with 1, 2, 4 and 4+7 plumodenticulate setae, respectively; exopod 2-segmented, distal segment with 2 terminal and 6 subterminal plumose setae; pereiopod IV (Fig. 13D) coxopod naked; basipod with 2 plumodenticulate setae; endopod 5segmented with 2, 2, 2, 3+1 and 3 plumodenticulate setae, respectively; exopod with 2 terminal and 6 subterminal plumose natatory setae; pereiopod V (Fig. 13E) rudimentary. Pleopod (Fig. 11A) biramous. Abdomen (Fig. 11A) five somites with rounded posteriolateral angles. Telson (Fig. 11C) posterior margin with 5 pairs of plumose setae; uropod (Fig. 11C) exopod and endopod with several long plumose setae. 


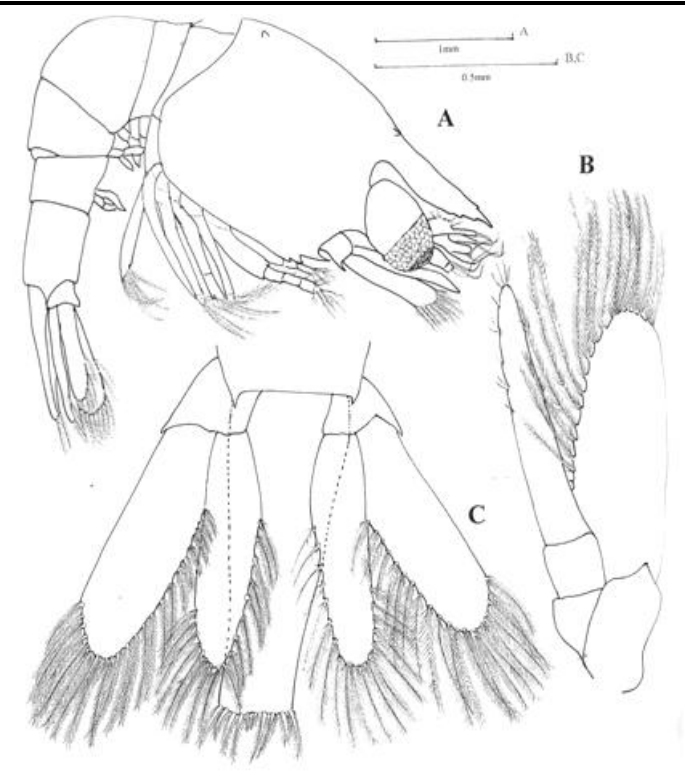

Fig11. Saron marmoratus (Olivier, 1811). Zoea V: A, entire, lateral view; B, antenna; $C$, telson, with uropods

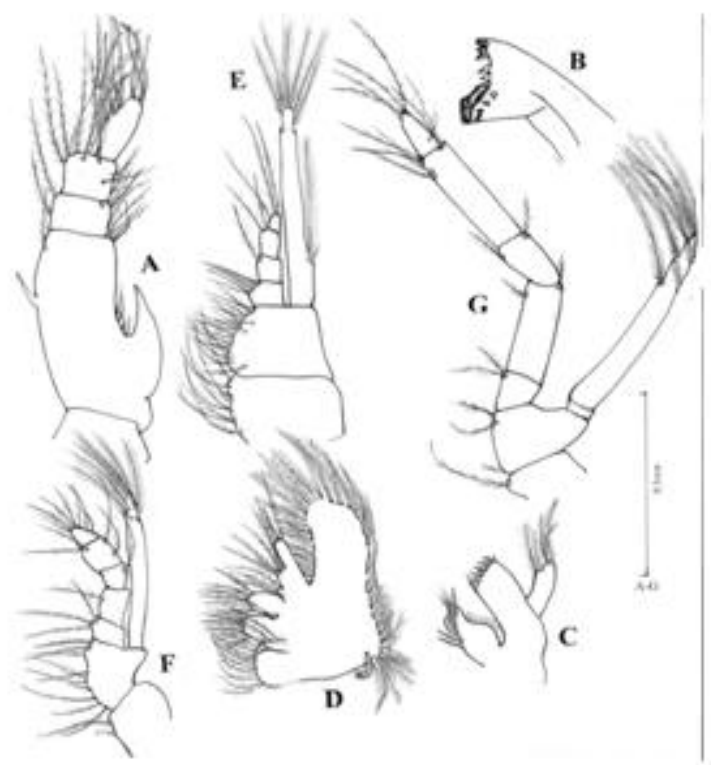

Fig12. Saron marmoratus (Olivier, 1811). Zoea V: A, antennule; B, mandible; C, maxillule; D, maxilla; E-G, maxillipeds I - III

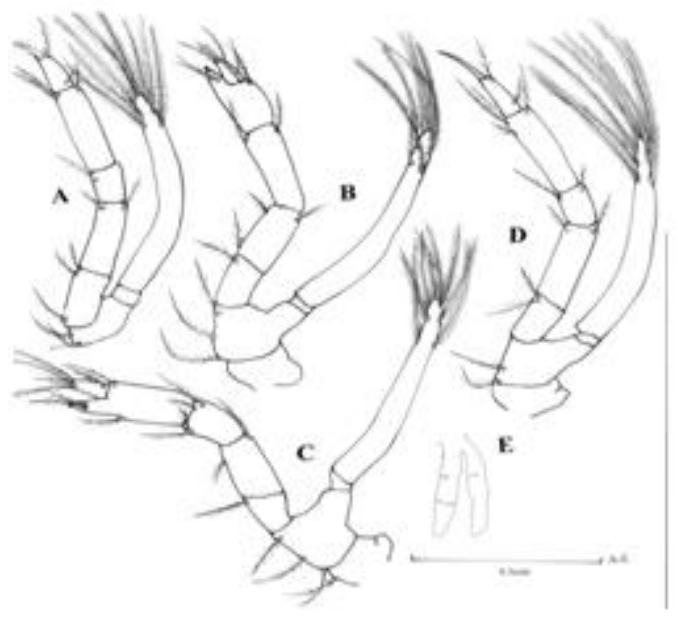

Fig13. Saron marmoratus (Olivier, 1811). Zoea $V: A-E$, pereiopods I $-V$ 
Zoea VI (Figs. 14A - 16E)

Size: $-\mathrm{TL}=7.00 \mathrm{~mm}-7.52 \mathrm{~mm}$

Duration: - 6 days

Diagnostic Features: - Carapace (Figs. 14A, B) smooth with a mediodorsal hump and one small posterior marginal spine present; rostrum with 1 spine on the dorsal side and 3 on the ventral side; pterygostomian spine present. Antennule (Fig. 14C) peduncle 3 -segmented with 2 (spine) $+8,2+4$ and 6 setae, respectively; inner ramus (endopod) with 2 setae; outer ramus (exopod) with 7 aesthetascs. Antenna (Fig. 14D) endopod 2-segmented, distal segment with 2 simple setae; number of scaphocerite (exopod) setae increased. Mandible (Fig. 14E) incisor and molar process well developed. Maxillule (Fig. 15A) coxal endite with 13 plumodenticulate setae; basial endite with 16 cuspidate and 6 plumodenticulate sete; endopod with 3 terminal and 2 subterminal setae. Maxilla (Fig. 15B) coxal and basial endites bilobed with $10+4$ and $6+8$ plumodenticulate setae, respectively; endopod with 7 plumodenticulate setae; scaphognathite with 39 setae. Maxilliped I (Fig. 15C) coxal endite with 6 and basial endte with 20 plumodenticulate setae, respectively; endopod 4-segmented with 4, 2, 2 and 4 plumodenticulate setae, respectively; exopod 2-segmented, proximal segment with 2 and distal segment with 2 terminal and 4 subterminal plumose natatory setae. Maxilliped II (Fig. 15D) coxal endite naked; basial endite with 9 plumodenticulate setae; endopod 5-segmented with 3, 1, 0, 3 and $6+1$ plumodenticulate setae, respectively; exopod 2-segmented, distal segment with 2 terminal and 4 subterminal plumose natatory setae. Maxilliped III (Fig. 15E) coxal endite with 1 plumodenticulate seta; basial endite with 1 plumodenticulate seta; endopod 5-segmented with 1, 1, 1, 2 and 3 plumodenticulate setae, respectively; exopod 2- segmented, terminal segment with 2 terminal and 6 subterminal plumose natatory setae. Pereiopods I-V (Figs. 15F, 16A-D) biramous; pereiopod I (Fig. 15F) coxopod naked; basipod with 3 plumodenticulate setae; endopod 4- segmented with 2, 3, 6 and 4 plumodenticulate setae, respectively; exopod with 2 terminal and 6 subterminal plumose natatory setae; pereiopod II (Fig. 16A) coxopod with 1 spine; basipod with 3 plumodenticulate setae; endopod 4-segmented with 2, 1, 3,5 +4 plumodenticulate setae, respectively, distal segment chelate; exopod 2 -segmented, distal segment with 2 terminal and 6 subterminal plumose setae; pereiopod III (Fig. 16B) coxopod naked; basipod with 2 plumodenticulate setae; endopod 5-segmented with 1, 3, 2, 5 and $2+1$ plumodenticulate setae, respectively; exopod 2-segmented, distal segment with 2 terminal and 6 subterminal plumose natatory setae; pereiopod IV (Fig. 16C) coxopod with spine; basipod with 1 seta; endopod 5-segmented with 1, 2, 1, 3 and 3 plumodenticulate setae, respectively; exopod 2-segmented, distal segment with 2 terminal and 6 subterminal plumose natatory setae; pereiopod V (Fig. 16D) coxopod naked; basipod with 1 seta; endopod 4-segmented with 2, 2, 3 and $4+2$ plumodenticulate setae, respectively, distal segment chelate; exopod 2-segmented with 2 terminal and 6 subterminal plumose natatory setae. Pleopod (Fig. 16E) biramous; endopod naked; exopod with 5 setae (setae broken). Abdomen (Fig. 14A) five somites with rounded posteriolateral angles. Telson (Fig. 14A) posterior margin with 5 pairs of setae; uropod (Fig. 14A) exopod and endopod with several long plumose setae.

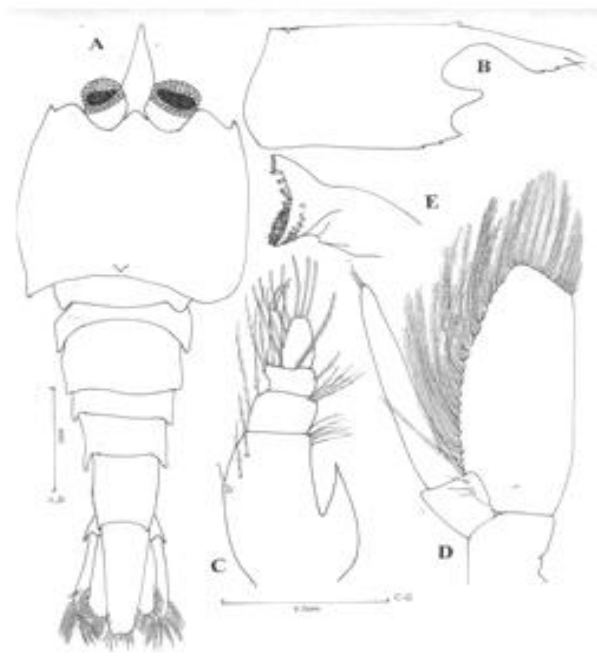

Fig14. Saron marmoratus (Olivier, 1811). Zoea VI: A, entire, dorsal view; B, lateral view of carapace; C, antennule; D, antenna; E, mandible 


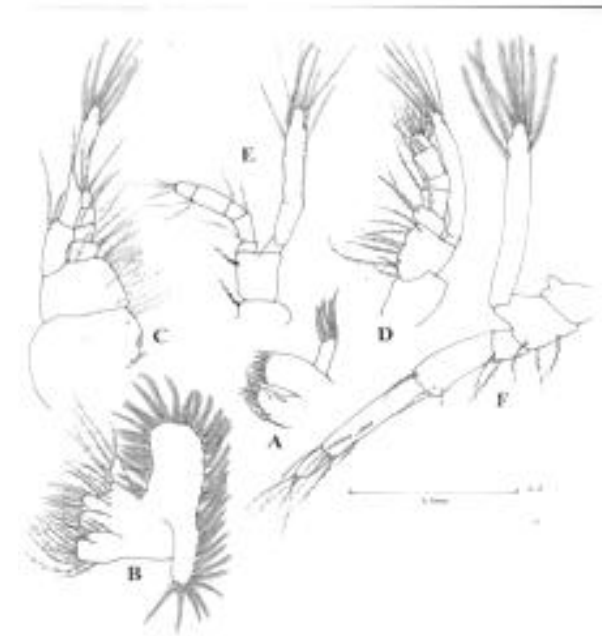

Fig15. Saron marmoratus (Olivier, 1811). Zoea VI: A, maxillule; B, maxilla; $C$ - E, maxillipeds I- III; F, pereiopod I

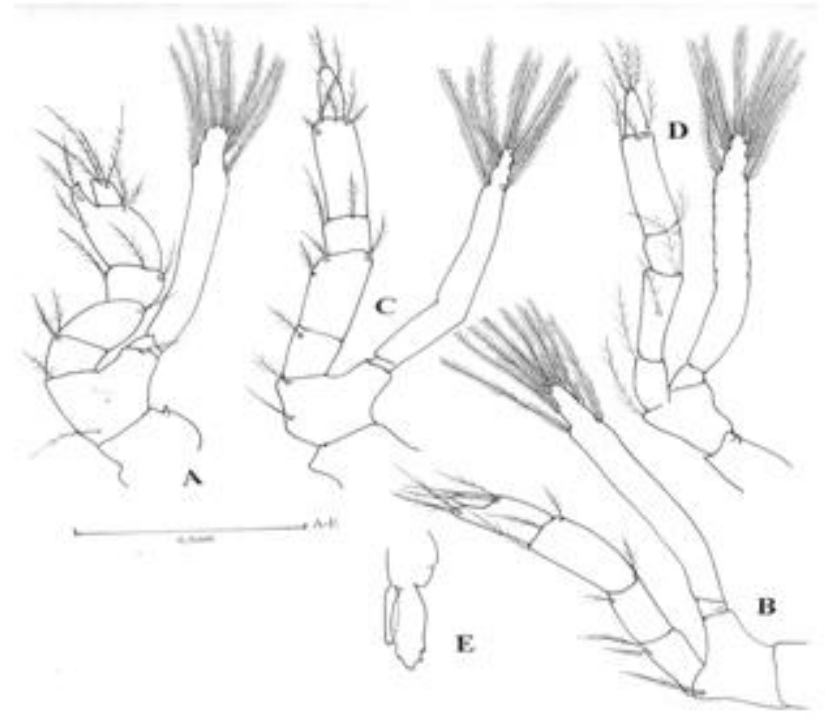

Fig16. Saron marmoratus (Olivier, 1811). Zoea VI: A-D, pereiopods II-V; E, pleopod

Postlarva I (Figs. 17A - 19E)

Size: $-\mathrm{TL}=7.93 \mathrm{~mm}-8.30 \mathrm{~mm}$

Duration: - 5 days

Diagnostic Features: Carapace (Figs. 17A, B) smooth; antennal and pterygostomian spine present; rostrum slightly upturned and bears 6 ventral spine with fine plumose setae and 6 dorsal spine of which 5 are on the carapace. Antennule (Fig. 17C) peduncle 3-segmented, lateral margin of basial segment produced into a blunt process (stylocerite) reaching middle of second segment of second antennular peduncle; segment 2 and 3 bear 5 and 4 setae, respectively; inner ramus (endopod) 5 segmented with 0, 0, 0, 2 and 5 simple setae, respectively; outer ramus (exopod) 5-segmented with 5, 3, 3, 4 and 0 aesthetascs, respectively; terminal segment with 4 simple setae. Antenna (Fig. 17D) peduncle 3-segmented; flagellum multi articulated with small setae; scaphocerite with several long plumose setae and 1 distolateral spine. Mandible (Fig. 17E) well developed. Maxillule (Fig. 17F) coxal endite with 9 plumodenticulate setae; basial endite with 27 cuspidate and 4 plumodenticulate setae; endopod with 2 plumodenticulate setae. Maxilla (Fig. 17G) coxal and basial endite bilobed with $4+6$ and $10+15$ plumodenticulate setae, respectively; endopod with 1 plumodenticulate seta; scaphognathite with 48 setae. Maxilliped I (Fig. 18A) coxopod naked; basipod with several plumodenticulate setae; 3 -segmented, endopod with 0,2 and 1 plumodenticulate setae; exopod with 2 terminal and 4 subterminal plumose and 5 lateral marginal plumodenticulate setae. Maxilliped II (Fig. 18B) coxopod with 1 seta; basipod naked; 5-segmented, endopod with 3, 3, 2, 9 and 16 plumodenticulate setae, respectively; 2-segmented, exopod distal segment with 2 terminal 4 
subterminal plumose setae. Maxilliped III (Fig. 18C) coxopod broken; basipod with 4 plumodenticulate setae; endopod with 5 plumodenticulate setae; exopod 2 -segmented, distal segment with 2 terminal and 4 subterminal plumose setae. Pereiopods I-V (Figs. 18D, E, 19A-C) pereiopods IIII chelate (Figs. 18D, E, 19A); pereiopods IV and V (Figs. 19B, C) biunguiculate; superior unguis longer than inferior. Pleopod (Fig. 19D) biramous; endopod with 5 plumose setae; exopod with 10 plumose natatory setae. Telson (Fig. 19E) dorsal surface with 2 pairs of spines and few setae; posterior margin with 2 pairs of spines and 2 pairs of long plumose setae; posteriolateral margin with 4 pairs of long plumose setae; uropods with several setae.

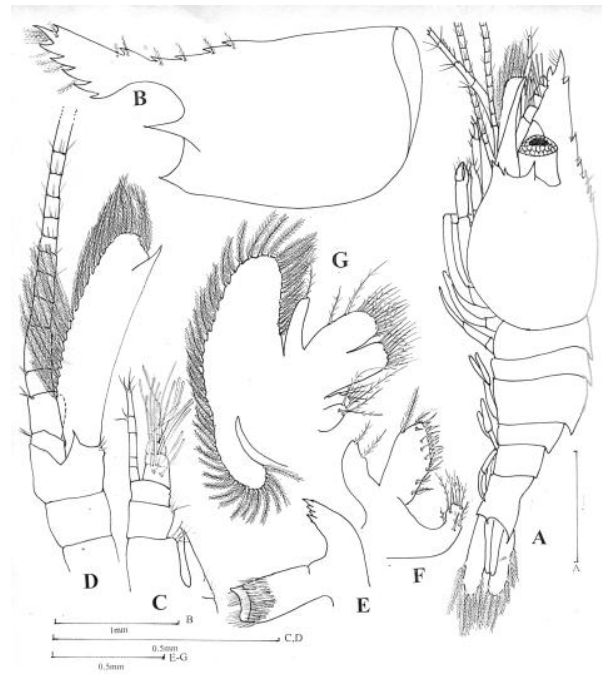

Fig17. Saron marmoratus (Olivier, 1811). Postlarva I: A, entire, lateral view; B, lateral view of carapace; $C$, antennule; $D$, antenna; $E$, mandible; $F$, maxillule; $G$, maxilla

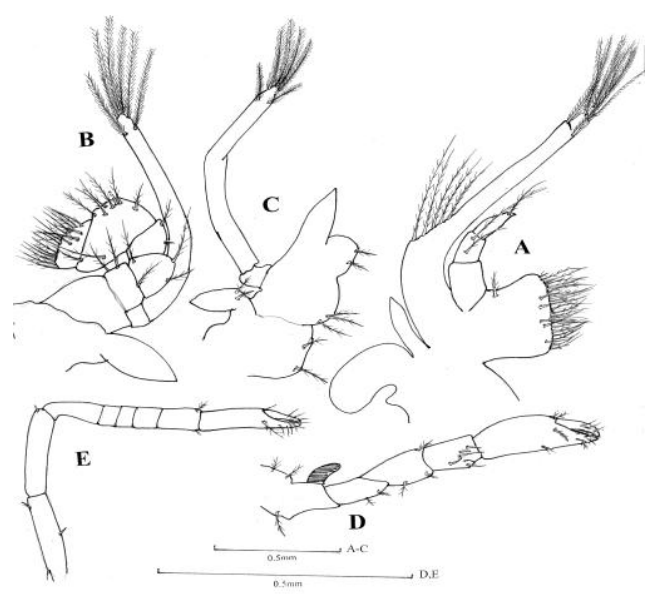

Fig18. Saron marmoratus (Olivier, 1811). Postlarva I: A-C, maxillipeds I- III; D, E, pereiopods I, II

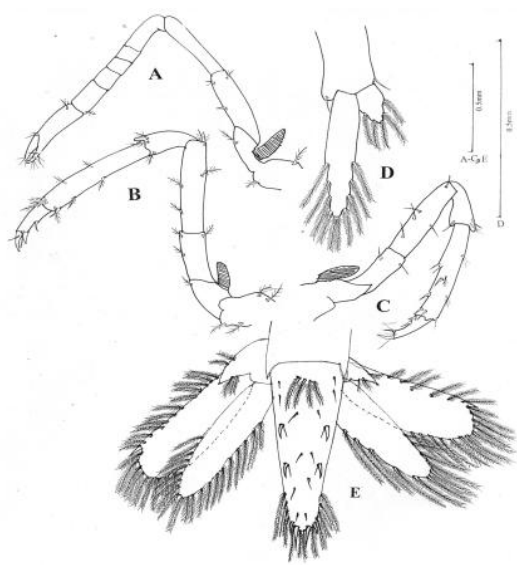

Fig19. Saron marmoratus (Olivier, 1811). Postlarva I: A-C, pereiopods III-V; D, pleopod; E, telson, with uropods. 
Farhana S. Ghory et al.

Postlarva II (Figs. 20A - 22C)

Size:- TL $=8.73 \mathrm{~mm}-9.00 \mathrm{~mm}$

Duration:- 3 days

Diagnostic Features: Carapace (Fig. 20A) smooth; antennal and pterygostomian spine present; rostrum bear 6 ventral spine with fine setae and 8 dorsal spine with fine setae. Antennule (Fig. 20B) peduncle 2-segmented, lateral margin of basial segment produced into a blunt process (stylocerite) reaching first antennal peduncle segment, segment 1 and 2 with 8 and 5 plumodenticulate setae; inner ramus (endopod) 7-segmented with fine setae; outer ramus (exopod) 7-segmented with 0, 6, 2, 2, 2, 1, 0 aesthetscs, respectively, terminal segment with 3 plumodenticulate setae. Antenna (Fig. 20C) peduncle 3-segmented; flagellum multi articulated with small setae; scaphocerite with several setae and 1 distolateral spine. Mandible (Fig. 20D) incisor and molar processes well developed; endopod bud rudimentary. Maxillule (Fig. 20E) coxal endite with 13 plumodenticulate setae; basial endite with 17 cuspidate and 16 plumodenticulate setae; endopod with 2 plumodenticulate setae. Maxilla (Fig. 20F) coxal and basial endites bilobed with $5+2$ and $7+9$ plumodenticulate setae, respectively; endopod with 2 plumodenticulate setae; scaphognathite with several setae. Maxilliped I (Fig. 20G) coxopod and basipod with several setae; endopod 3-segmented with 1, 1 and 2 plumodenticulate setae, respectively; exopod with $2+4+13$ setae. Maxilliped II (Fig. 21A) coxopod broken; basipod with 7 plumodenticulate setae; 5-segmented, endopod with 2, 2, 3,6 and 13 plumodenticulate setae, respectively; exopod with 4 terminal and 4 subterminal plumose natatory setae. Maxilliped III (Fig. 21B) coxopod with 1 seta; basipod with 11 plumodenticulate setae; 3 -segmented, endopod each with several small plumodenticulate setae; 2-segmented, exopod terminal segment with 2 terminal and 6 subterminal plumose natatory setae. Pereiopods I-V (Figs. 21C-F, 22A) pereiopods I and II (Figs. 21C, D) chelate; pereiopods III - V (Figs. 21E, F and 22A) biunguiculate; superior unguis longer than inferior. Pleopod (Fig. 22B) endopod with 11 plumose setae; excpod with 12 plumose natatory setae. Telson (Fig. 22C) dorsal surface with 2 pairs of spines and few setae; posterior margin with 2 pairs of spines and 2 pairs of long plumose setae; posteriolateral margin with 5 pairs of long plumose setae; uropods with several setae.



Fig20. Saron marmoratus (Olivier, 1811). Postlarva II: A, entire, lateral view; B, antennule; C, antenna; D, mandible; E, maxillule; F, maxilla; $G$, maxilliped I

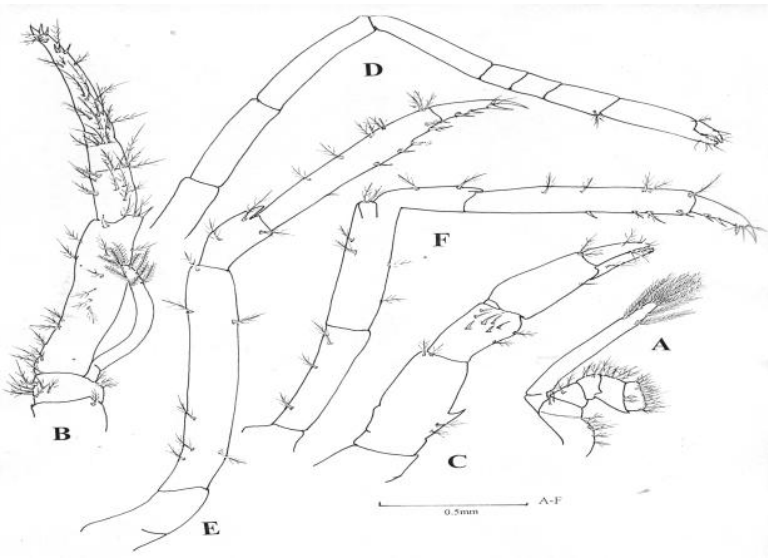

Fig21. Saron marmoratus (Olivier, 1811). Postlarva II: A, B, maxillipeds I, II; C - F, pereiopods I - IV 


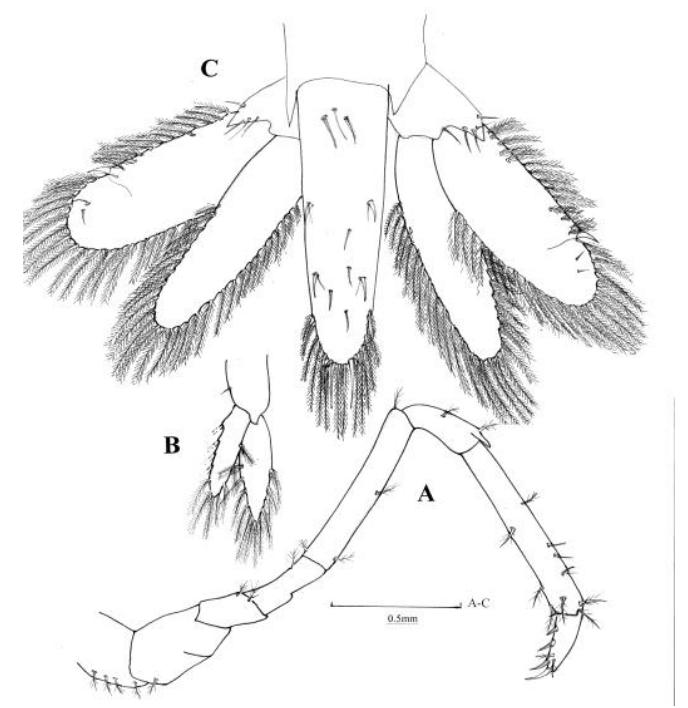

Fig22. Saron marmoratus (Olivier, 1811). Postlarva II: A, pereiopod V; B, pleopod; C, telson, with uropods

Postlarva III (Fig. 23A - E)

Size: $-\mathrm{TL}=9.00 \mathrm{~mm}-9.50 \mathrm{~mm}$

Duration: - 11days

Diagnostic Features: Rostrum (Fig. 23A) rostrum bears 8 ventral spines with fine setae and 7 dorsal spines with fine setae. Antennule (Fig. 23B) peduncle 2-segmented, lateral margin of basial segment with 2 spines and 9 setae, segment 1 with 9 setae; inner ramus (endopod) 9- segmented with few fine setae; outer ramus (exopod) 8-segmented with $0,1,6,2,4,6,0$ and 0 aesthetascs, respectively; proximal segment of exopod with 4 setae, distal segment with 2 terminal setae. Antenna (Fig. 23C) peduncle 3-segmented; flagellum multi articulated with small setae; scaphocerite with several long plumose setae and 1 distolateral spine. Mandible (Fig. 23D). Well developed 3-segmented, endopod bud present with 0,2 and 3 fine setae. Telson (Fig. 23E) dorsal surface with 2 pairs of spines and few setae; posterior margin with 1 pair of spine and 1 pair of long plumose setae; posteriolateral margin with 1 pair of spine and 8 pairs of long plumose setae; uropods with several setae.

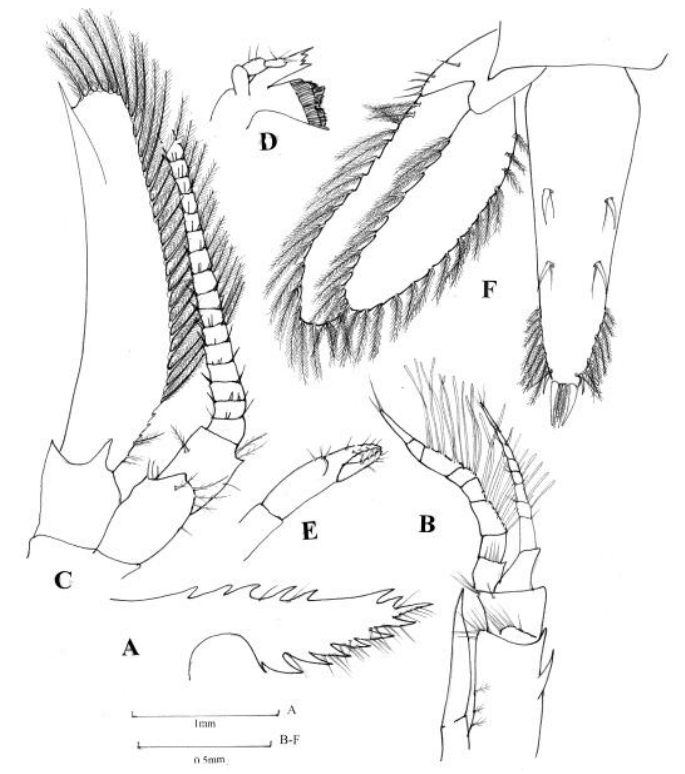

Fig23. Saron marmoratus (Olivier, 1811). Postlarva III: A, lateral view of rostrum; B, antennule; C, antenna; $D$, mandible; E, pereiopod II; F, telson, with left, uropod

\section{Postlarva IV (Fig. 24A - F)}

Size:- $\mathrm{TL}=9.50 \mathrm{~mm} 9.70 \mathrm{~mm}$

Duration:- 14 days 
Diagnostic Features: Rostrum (Fig. 24A) rostrum bears 7 ventral spines with fine setae and 6 dorsal spines with fine setae. Antennule (Fig. 24B) peduncle 2-segmented, lateral margin of basial segment with 2 spines and 12 setae, segment 1 with 4 setae; inner ramus (endopod) segmented with few fine setae; outer ramus (exopod) 8-segmented with 5, 5, 4, 3, 4, 6, 0 and 0 aesthetascs, respectively, proximal segment of exopod with 4 setae, distal segment with 2 terminal setae. Antenna (Fig. 24C) peduncle 3-segmented; flagellum multi articulated with small setae; scaphocerite with several long plumose setae and 1 distolateral spine. Mandible (Fig. 24D) well developed 3-segmented endopod bud present with 0, 2 and 3 fine setae. Pereiopod II (Fig. 24E) chelate. Telson (Fig. 24F) dorsal surface with 2 pairs of spines and few setae; posterior margin with 2 pairs of spines and 2 pairs of long plumose setae; posteriolateral margin with 7 pairs of plumose setae; uropods with several setae.

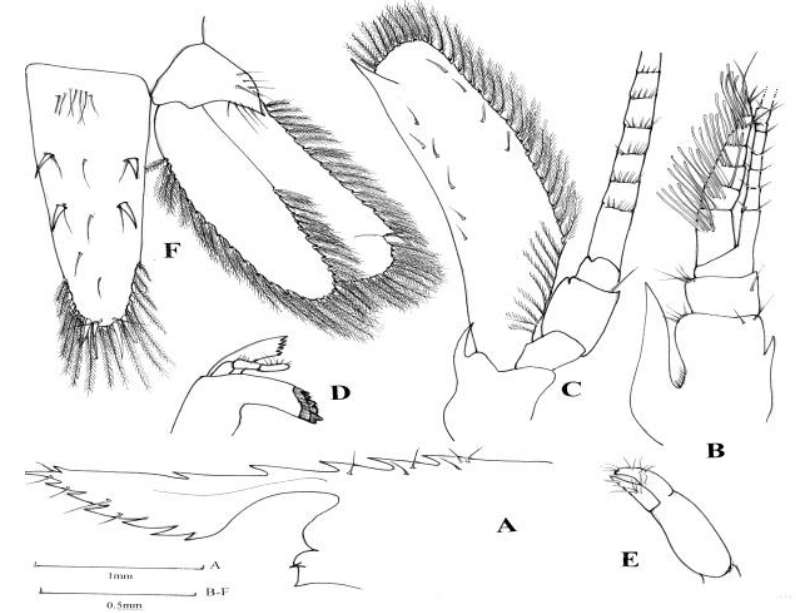

Fig24. Saron marmoratus (Olivier, 1811). Postlarva IV: A, lateral view of rostrum; B, antennule; $C$, antenna; $D$, mandible; E, pereiopod II; F, telson, with right, uropod

\section{Postlarva V (Fig. 25A - D)}

Size: $-\mathrm{TL}=9.72 \mathrm{~mm}-9.80 \mathrm{~mm}$

Duration: - 7 days

Diagnostic Features: Rostrum (Fig. 25A) rostrum bears 8 ventral spines with fine setae and 6 dorsal spines with fine setae. Antennule (Fig. 25B) peduncle 2-segmented, lateral margin of basial segment with 2 spines and 5 setae, segment 1 with 3 setae; inner ramus (endopod) segmented with few fine setae; outer ramus (exopod) 9-segmented with 6, 6, 5, 4, 3, 5, 0, 0, and 0 aesthetascs, respectively, proximal segment of exopod with 1 seta, distal segment with 2 terminal setae. Antenna (Fig. 25C) peduncle 3-segmented; flagellum multi articulated with small setae; scaphocerite with several long plumose setae and 1 distolateral spine. Telson (Fig. 25D) dorsal surface with 2 pairs of spines and few setae; posterior margin with 2 pairs of spines and 4 pairs of long plumose setae; posteriolateral margin with 7 pairs of plumose setae; uropods with several setae.

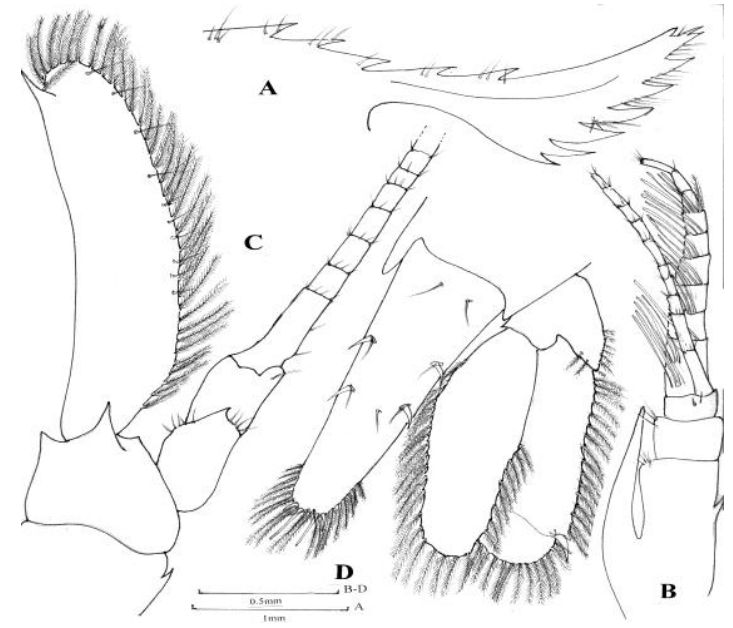

Fig25. Saron marmoratus (Olivier, 1811). Postlarva V: A, lateral view of rostrum; B, antennule; $C$, antenna; $D$, telson, with left, uropod 
Postlarva VI (Fig. 26A - E)

Size: $-\mathrm{TL}=9.78 \mathrm{~mm}-10.00 \mathrm{~mm}$

Duration: - 11 days

Diagnostic Features: Rostrum (Fig. 26A) rostrum bears 8 ventral spines with fine setae and 6 dorsal spines with fine setae. Antennule (Fig. 26B) peduncle 2-segmented, lateral margin of basial segment with 2 spines and 8 setae, segment 1 with 4 setae; inner ramus (endopod) segmented with few fine setae; outer ramus (exopod) 11-segmented wit 6, 7, 8, 6, 6, 3, 2, 0, 0, 0 and 0 aesthetascs, respectively, proximal segments of exopod with few setae, distal segment with 2 terminal setae. Antenna (Fig. 26C) peduncle 3-segmented; flagellum multi articulated with small setae; scaphocerite with several long plumose setae and 1 distolateral spine. Mandible (Fig. 26D) well developed 3-segmented endopod bud present with 6, 3 and 5 fine setae. Telson (Fig. 26E) dorsal surface with 2 pairs of spines and few setae; posterior margin with 2 pairs of spines and 3 pairs of plumose setae; posteriolateral margin with 9 pairs of long plumose setae; uropods with several setae.

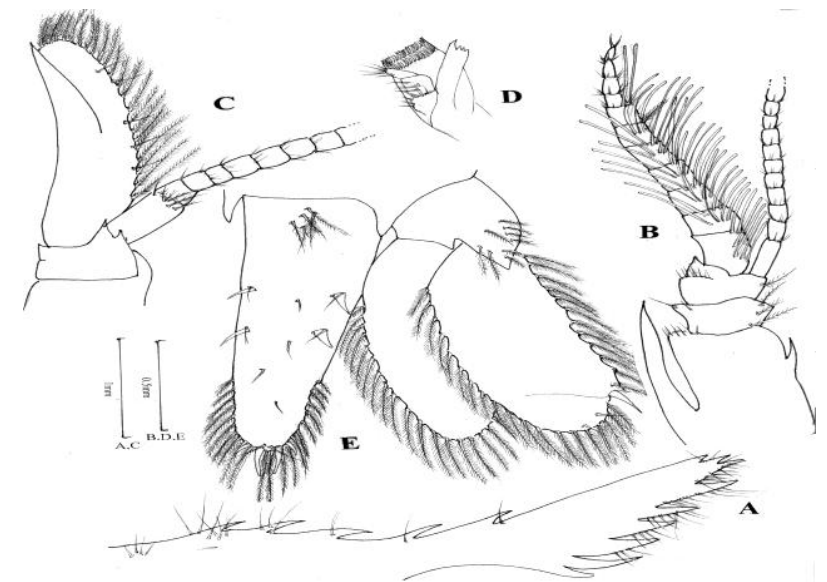

Fig26. Saron marmoratus (Olivier, 1811). Postlarva VI: A, lateral view of rostrum; B, antennule; C, antenna; $D$, mandible; E, telson, with right, uropod

\section{Postlarva VII (Fig. 27A-D)}

Size: $-\mathrm{TL}=10.8 \mathrm{~mm}$

Duration: - 2 days (died).

Diagnostic Features: Rostrum (Fig. 27A) rostrum bears 8 ventral spines with fine setae and 6 dorsal spines with fine setae. Antennule (Fig. 27B) peduncle 2-segmented, lateral margin of basial segment with 2 spines and 4 setae, segment 1 with 3 setae; inner ramus (endopod) segmented with few fine setae; outer ramus (exopod) 12-segmented with 5, 3, 2, 3, 6, 3, 4, 2, 0, 0, 0 and 0 aesthetascs, respectively, proximal segments of exopod with few setae, distal segment with 2 terminal setae. Antenna (Fig. 27C) peduncle 3-segmented; flagellum multi articulated with small setae; scaphocerite with several long plumose setae and 1 distolateral spine. Telson (Fig. 27D) dorsal surface with 2 pairs of spines and few setae; posterior margin with 2 pairs of spines and 4 pairs of setae; posteriolateral margin with 9 pairs of plumose setae; uropod with several setae.

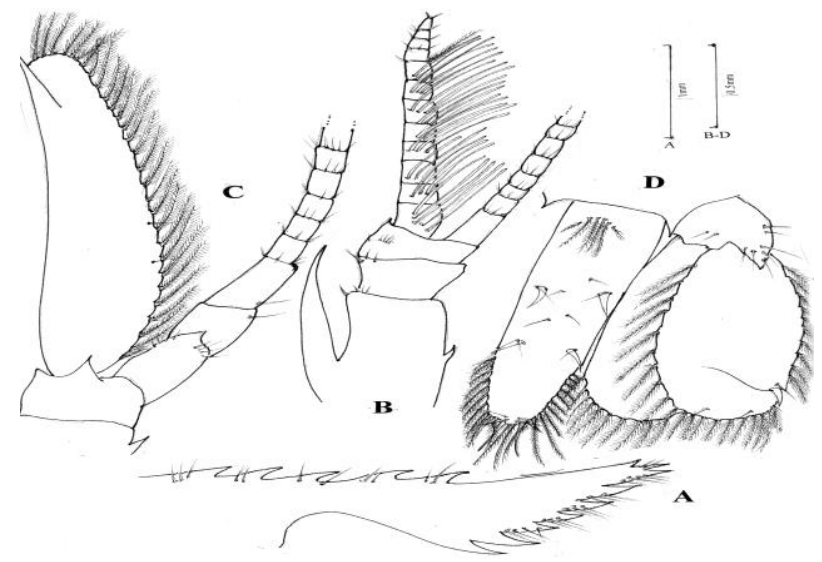

Fig27. Saron marmoratus (Olivier, 1811). Postlarva VII: A, lateral view of rostrum; $B$, antennule; $C$, antenna; $D$, telson, with right, uropod 
Farhana S. Ghory et al.

Table1. Comparison between laboratory reared Zoea I - V and postlarva I- IV of Saron marmoratus (present study) and previously studied larvae of same species

\begin{tabular}{|c|c|c|c|}
\hline Characters & $\begin{array}{l}\text { S. marmoratus } \\
\text { present study }\end{array}$ & $\begin{array}{c}\text { S. marmoratus } \\
\text { Sankolli \& Kewalramani } \\
(\mathbf{1 9 6 2 )}\end{array}$ & $\begin{array}{c}\text { S. marmoratus } \\
\text { Maihara \& Kyoya } \\
(\mathbf{2 0 0 2 )}\end{array}$ \\
\hline \multicolumn{4}{|l|}{ Zoea I: } \\
\hline \multicolumn{4}{|l|}{ Antennule: } \\
\hline Inner ramus & 1 seta & 4 setae & 1 seta \\
\hline Outer ramus & 2 aesthetascs +1 seta & 4 aesthetascs & 1 aesthetasc +3 setae \\
\hline \multicolumn{4}{|l|}{ Telson: } \\
\hline Posterior margin & 6 pairs of setae & 7 pairs of setae & 7 pairs of setae \\
\hline \multicolumn{4}{|l|}{ Zoea II: } \\
\hline \multicolumn{4}{|l|}{ Maxillule: } \\
\hline Coxal endite & 10 setae & 8 setae & 7 setae \\
\hline Basial endite & $13+1$ setae & 10 setae & 6 setae \\
\hline Endopod & 5 setae & 4 setae & 5 setae \\
\hline \multicolumn{4}{|l|}{ Maxilla: } \\
\hline Coxal endite & $16+4$ setae & $9+3$ setae & $12+3$ setae \\
\hline Basial endite & $8+9$ setae & $4+5$ setae & $4+3$ setae \\
\hline Scaphognathite & 15 setae & 19 setae & 12 setae \\
\hline \multicolumn{4}{|l|}{ Maxilliped I: } \\
\hline Basipod & 18 setae & 9 setae & several setae \\
\hline Endopod & $\begin{array}{l}\text { 4-segmented with } \\
4,1,2+1,3 \text { setae }\end{array}$ & $\begin{array}{l}\text { 4-segmented with } \\
4,2,2,3 \text { setae }\end{array}$ & $\begin{array}{l}\text { 4-segmented with } \\
3,1,3,3 \text { setae }\end{array}$ \\
\hline \multicolumn{4}{|l|}{ Maxilliped II: } \\
\hline Basipod & 7 setae & 10 setae & 6 setae \\
\hline Endopod & $\begin{array}{c}\text { 5-segmented with } \\
3+1,1,1,2+1,7+1 \\
\text { setae } \\
\end{array}$ & $\begin{array}{l}\text { 4-segmented with } \\
2,0,2,4 \text { setae }\end{array}$ & $\begin{array}{c}\text { 5-segmented with } \\
2+1,1,1,2+1,5 \text { setae }\end{array}$ \\
\hline \multicolumn{4}{|l|}{ Maxilliped III: } \\
\hline Basipod & 3 setae & 5 setae & 4 setae \\
\hline Endopod & $\begin{array}{l}\text { 5-segmented with } \\
1,1,1,2,4 \text { setae }\end{array}$ & $\begin{array}{l}\text { 4-segmented with } \\
1,1,2+1,4 \text { setae }\end{array}$ & $\begin{array}{c}5 \text {-segmented with } \\
2,1,1,2+1,2 \text { setae }\end{array}$ \\
\hline \multicolumn{4}{|l|}{ Zoea III: } \\
\hline \multicolumn{4}{|l|}{ Antennule: } \\
\hline Aesthetascs & 3 & 5 & 3 \\
\hline \multicolumn{4}{|l|}{ Maxillule: } \\
\hline Coxal endite & 10 seta & 6 setae & 7 setae \\
\hline Endopod & 5 setae & 4 setae & 5 setae \\
\hline \multicolumn{4}{|l|}{ Telson: } \\
\hline Posterior marginal setae & 7 pairs & 5 pairs & 7 pairs \\
\hline \multicolumn{4}{|l|}{ Zoea IV: } \\
\hline \multicolumn{4}{|l|}{ Antennule: } \\
\hline Aesthetascs & 6 & - & 3 \\
\hline Setae & Absent & - & 2 \\
\hline \multicolumn{4}{|l|}{ Maxillule: } \\
\hline Coxal endite & 13 setae & - & 8 setae \\
\hline Basial endite & $14+2$ setae & - & 7 setae \\
\hline Endopod & $2+2$ setae & - & $2+3$ setae \\
\hline \multicolumn{4}{|l|}{ Maxilla: } \\
\hline Endopod & 9 setae & - & 8 setae \\
\hline Scaphognathite & 34 setae & - & 22 setae \\
\hline \multicolumn{4}{|l|}{ Zoea V: } \\
\hline \multicolumn{4}{|l|}{ Antennule: } \\
\hline Aesthetascs & 9 & - & 7 \\
\hline Setae & Absent & - & 2 \\
\hline \multicolumn{4}{|l|}{ Maxillule: } \\
\hline Coxal endite & 10 setae & - & 8 setae \\
\hline Basial endite & 13 setae & - & 13 setae \\
\hline
\end{tabular}


Complete Larval Development of Saron marmoratus (Olivier, 1811) Reared Under Laboratory Conditions (Crustacea: Decapoda: Hippolytidae)

\begin{tabular}{|c|c|c|c|}
\hline Maxilla: & & & \\
\hline Endopod & 10 setae & - & 9 setae \\
\hline Scaphognathite & 34 setae & - & 29 setae \\
\hline \multicolumn{4}{|l|}{ Postlarva I: } \\
\hline \multicolumn{4}{|l|}{ Rostrum: } \\
\hline Ventral spines & 6 spines & 3 spines & 4 spines \\
\hline Dorsal spines & 6 spines & 1 spine & 8 spines \\
\hline \multicolumn{4}{|l|}{ Antennule: } \\
\hline Inner ramus & 5-segmented & unsegmented & 3-segmented \\
\hline \multicolumn{4}{|l|}{ Antenna: } \\
\hline Scaphocerite & $\begin{array}{c}\text { distolateral spine } \\
\text { present }\end{array}$ & distolateral spine absent & $\begin{array}{c}\text { distolateral spine } \\
\text { present }\end{array}$ \\
\hline Mandibular palp: & absent & absent & present \\
\hline \multicolumn{4}{|l|}{ Telson: } \\
\hline Posterior margin & $\begin{array}{c}2 \text { pairs of spines }+2 \\
\text { setae }\end{array}$ & 6 pairs of setae & 6 pairs of setae \\
\hline Posteriolateral margin & 4 pairs of setae & setae absent & setae absent \\
\hline \multicolumn{4}{|l|}{ Postlarva II: } \\
\hline \multicolumn{4}{|l|}{ Rostrum: } \\
\hline Dorsal spines & 8 spines & 5 spines & 6 spines \\
\hline \multicolumn{4}{|l|}{ Antennule: } \\
\hline Peduncle & 2-segmented & 3-segmented & 3-segmented \\
\hline Inner ramus & 7-segmented & 2-segmented & 3-segmented \\
\hline Outer ramus & $\begin{array}{c}\text { 7-segmented with } 0,6 \\
2,2,2,1,0 \\
\text { aesthetascs }\end{array}$ & $\begin{array}{l}\text { 3-segmented with } \\
5 \text { aesthetascs }\end{array}$ & $\begin{array}{l}\text { 5-segmented with } \\
\text { several setae }\end{array}$ \\
\hline Mandibular palp: & present & absent & present \\
\hline \multicolumn{4}{|l|}{ Telson: } \\
\hline Posterior margin & $\begin{array}{c}2 \text { pairs of spines }+2 \\
\text { pairs of setae }\end{array}$ & 4 pairs of setae & 3 pairs of setae \\
\hline Posteriolateral margin & 5 pairs of setae & 1 pair of setae & 3 pairs of setae \\
\hline \multicolumn{4}{|l|}{ Postlarva III: } \\
\hline \multicolumn{4}{|l|}{ Rostrum: } \\
\hline Ventral spines & 8 spines & 6 spines & - \\
\hline \multicolumn{4}{|l|}{ Antennule: } \\
\hline Inner ramus & 9-segmented & 4-segmented & - \\
\hline Outer ramus & 8-segmented & 4-segmented & - \\
\hline \multicolumn{4}{|l|}{ Telson: } \\
\hline Posterior margin & $\begin{array}{l}1 \text { pair of spines }+1 \\
\text { seta }\end{array}$ & 2 pairs of setae & - \\
\hline Posteriolateral margin & $\begin{array}{c}1 \text { pair of spines }+8 \\
\text { pairs of setae }\end{array}$ & 5 pairs of setae & - \\
\hline \multicolumn{4}{|l|}{ Postlarva IV: } \\
\hline \multicolumn{4}{|l|}{ Rostrum: } \\
\hline Ventral spines & 7 spines & 6 spines & - \\
\hline Dorsal spines & 6 spines & 7 spines & - \\
\hline \multicolumn{4}{|l|}{ Telson: } \\
\hline Posterior margin & $\begin{array}{l}2 \text { pairs of spines }+2 \\
\text { pairs of setae }\end{array}$ & $\begin{array}{c}1 \text { pair of spines }+1 \text { pair of } \\
\text { setae }\end{array}$ & - \\
\hline Posteriolateral margin & 7 pairs of setae & 5 pairs of setae & - \\
\hline
\end{tabular}

Table2. Comparison between zoeae of S. marmoratus (present study) with previously studied zoeae of same species

\begin{tabular}{|l|c|c|c|c|c|}
\hline Characters & $\begin{array}{c}\text { S. marmoratus } \\
\text { present study }\end{array}$ & $\begin{array}{c}\text { S. } \\
\text { marmoratus } \\
\text { Gurney } \\
(\mathbf{1 9 3 7})\end{array}$ & $\begin{array}{c}\text { S. marmoratus } \\
\text { Al-Kholy (1961) }\end{array}$ & $\begin{array}{c}\text { S. marmoratus } \\
\text { Sankolli \& } \\
\text { Kewalramani (1962) }\end{array}$ & $\begin{array}{c}\text { S. marmoratus } \\
\text { Maihara \& } \\
\text { Kyoya (2002) }\end{array}$ \\
\hline $\begin{array}{l}\text { Zoea: } \\
\text { Rostrum }\end{array}$ & $\begin{array}{c}\text { present in all } \\
\text { stages }\end{array}$ & $\begin{array}{c}\text { absent in } \\
\text { zoea I }\end{array}$ & $\begin{array}{c}\text { present in all } \\
\text { stages }\end{array}$ & present in all stages & $\begin{array}{c}\text { present in all } \\
\text { stages }\end{array}$ \\
\hline
\end{tabular}


Farhana S. Ghory et al.

\begin{tabular}{|l|c|c|c|c|c|}
\hline $\begin{array}{l}\text { Zoea I: } \\
\text { Antennal } \\
\text { exopod }\end{array}$ & 4-segmented & 4-segmented & 4-segmented & 4-segmented & 2-segmented \\
\hline $\begin{array}{l}\text { Telson: } \\
\text { plumose } \\
\text { setae }\end{array}$ & 7 pairs & 7 pairs & 7 pairs & 7 pairs & 7 pairs \\
\hline $\begin{array}{l}\text { Pereiopods } \\
\text { (first } \\
\text { appearance) }\end{array}$ & zoea I & zoea I & zoea II & zoea II & zoea I \\
\hline $\begin{array}{l}\text { Pleopods } \\
\text { first } \\
\text { appearance) }\end{array}$ & zoea I & no mention & no mention & zoea II & zoea III \\
\hline
\end{tabular}

\section{REMARKS}

Al-Kholy (1961), Gurney (1937), Sankolli and Kewalramani (1962) and Maihara and Kyoya (2002) described the larval and early postlarval stages of Saron marmoratus reared in the laboratory. The protozoea of Sankolli and Kewalramani (1962) is equivalent to the first zoea, while their first postlarva is actually the fifth and last zoeal stage (Felder et al., 1985). Theirs 'second' postlarva (= decapodid) has functional pleopods and a rudimentary exopodite on the third maxilliped; the exopodites on the pereiopods are no longer present. The next postlarval stage has a rostrum characteristic of the adult. The protozoea to fourth post-larva passed within twenty six days. Maihara and Kyoya (2002) described the stage after the fifth zoea as megalopa (decapodid) and first juvenile stage. First juvenile stage is equivalent to postlarva II. We have obtained thirteen stages, six zoeal and seven postlarval. The zoea I to post-larva VII passed within eighty days. Perhaps a life history generalization is not possible.

The absence of anal spine in the first zoea was considered as characteristics of the genus Saron with three other hippolytids(Haynes,1985) but Terossi et al(2010)did not agree with this ; the given spine was missing in the Pakistani material.

During the present study the zoea VI moulted to postlarva I, a meaningful comparison was possible for zoea I - III with the available descriptions of S. marmoratus larvae by Sankolli and Kewalramani (1962), who were able to rear up to zoea I-III and Maihara and Kyoya (2002) who reared up to fifth zoea.(Table 1) Pakistani zoeal and postlarval stages compared with previously described $S$. marmoratus larvae differ in number of segments, spines and setae. We noticed differences in characters from those recorded by Al-Kholy (1961) from Red Sea, Gurney (1937) from Australia, Sankolli and Kewalramani (1962) from India and Maihara and Kyoya (2002) from Japan; these differences may be attributed to the different ecological characters agreeing with Sankolli and Kewalramani (1962) from India (Table 2). The larval duration in the Pakistani laboratory experiment was shorter i.e.25 days as compared to 30 days given in literature(Kruschwitz,1967)

It may also indicate presence of another species besides $S$. marmoratus in Pakistan. Sheibani- Tezerji and Sari (2007) are of the opinion that for the identification of adult Saron marmoratus, a range of characters with their intra and interpopulational variations should be considered. Debelius (2001) have given five colour patterns in Saron marmoratus. Our present mother female does match none of them. Kazmi (1996) while working on parasitized $S$. marmoratus by Parabopyrella marmoratus consulted Dr. Bourdon regarding a deviation in Pakistani host specimens from typical Saron marmoratus of Chace (1997) the absence of two subdistal spines on merus of fifth leg which are present in $S$. marmoratus. Bourdon wrote (pers. corr. QBK) that Pakistani species resembles S. neglectus (another Indo-Pacific species) and since the parasite is said to be host specific it needed verification. It needs to re-examine the collection housed in the depository of Marine Reference Collection \& Resource Centre.

\section{REFERENCES}

Al-Kholy, A.A. (1961). Larvae of some macruran crustacea (from the Red sea). Publ. Mar. Biol. Stn., Al-ghardaqa (Red sea) No. 2: 73-94.

Chace, F.A.Jr. (1997). The caridean shrimps (Crustacea: Decapoda) of the Albatross Philippine Expedition, 1907-1910, Part 7: Families Atyidae, Eugonatonotidae, Rhynchocinetidae, Bathyalemonellidae, Processidae, and Hippolytidae. Smithsonian Contributions to Zoology, 587: 1-106. 
Debelius, H. (2001). Crustacea Guide of the world: Shrimps, Crabs, Lobsters, Mantis shrimps, Amphipods. Pp 1-321. (Editions Ikan, Frankfurt-a-M).

Felder, D.L., J.W. Martin and J.W. Goy. (1985). Patterns in early postlarval development of decapods. In Larval Growth. Crustacean Issues, Vol. 2, edited by Adrian M. Wenner. Published by A.A. Balkema/ Rotterdam/ Boston: 163-225.

Gurney, R. (1937). Larvae of decapod Crustacea. Part IV. Hippolytidae. Discovery Report, 14: 351404.

Haynes, E.B. 1985. Morphological development, identification, and biology of larvae of Pandalidae, Hippolytidae, and Crangonidae (Crustacea, Decapoda) of the northern north Pacific Ocean. US Fish. Bull., 83: 253-288.

Kazmi, Q.B. (1996). Note on parasitized hippolytid caridean Saron marmoratus (Crustacea: Decapoda). MRC News Letter, 5(4): 4.

Kazmi,M. A. and Q.B. Kazmi. (1979). A check list of Marine Caridean Prawns of Pakistan. Biologia. Pakistan, 25(1\& 2): 151-157.

Kazmi, Q.B. and M.A. Kazmi. (2012). Biodiversity and Biogeography of Caridean shrimps of Pakistan, HEC Pakistan, pp. 400.

Kemp, S. (1914). Notes on Crustacea Decapoda in the Indian Museum. V. Hippolytidae. Records of the Indian Museum, 10:81-129. Kruschwitz, LG. 1967. Aspects of the behavior and ecology of a reef shrimp.American Zoologist 71204-205

Maihara, Y. and N. Kyoya. (2002). Larval stages of the Hippolytid shrimp, Saron marmoratus (Oliver, 1811) (Decapoda: Caridea: Hippolytidae) reared under laboratory conditions. Science Report Museum Tokai University, 4: 45-47.

Sankolli, K.N. and H.G. Kewalramani. (1962). Larval development of Saron marmoratus (Oliver), in the laboratory. Jour. Mar. Boil. Ass. India, 4(2): 106-120.

Sheibani-Tezerji, B. and A. Sari. (2007). First record of Saron marmoratus (Olivier, 1811) (Crustacea: Deccapoda: Hippolytidea) from Makran coast, Iran. Iranian Jour. Animal Biosystematics, 3(1): 69-75.

Terossi,M., J. A. Cuesta, I. S. Wehrtmann and F. 1.Mantelatto,2010.Revision of the larval morphology (Zoea I) of the family Hippolytidae Bate (Caridea), with a

description of the first stage of the shrimp Hippolyte obliquimanus Dana, 1852. digital.csic.es/ bitstream/10261/45431/3/hippolytidae_bate 